Article

\title{
Effect of Housing System and Rosemary and Cinnamon Essential Oils on Layers Performance, Egg Quality, Haematological Traits, Blood Chemistry, Immunity, and Antioxidant
}

\author{
Mahmoud M. Abo Ghanima ${ }^{1}\left(\mathbb{D}\right.$, Mohamed F. Elsadek $^{2,3, *}{ }^{\circledR}$, Ayman E. Taha ${ }^{4}{ }^{(}$, \\ Mohamed E. Abd El-Hack ${ }^{5}$ (D), Mahmoud Alagawany ${ }^{5}$ (D) Badreldin M. Ahmed ${ }^{2}$, \\ Mona M. Elshafie ${ }^{2}$ and Karim El-Sabrout ${ }^{6, *}$ (D) \\ 1 Animal Husbandry and Animal Wealth Development Department, Faculty of Veterinary Medicine, \\ Damanhour University, Damanhour 22511, Egypt; mmyvet2@yahoo.com \\ 2 Department of Community Health Sciences, College of Applied Medical Sciences, King Saud University, \\ Riyadh 11362, Saudi Arabia; Badreldin222@gmail.com (B.M.A.); melshafie@ksu.edu.sa (M.M.E.) \\ 3 Department of Nutrition and Food Science, Helwan University, Helwan 11795, Egypt \\ 4 Department of Animal Husbandry and Animal Wealth Development, Faculty of Veterinary Medicine, \\ Alexandria University, Edfina 22758, Egypt; ayman.taha@alexu.edu.eg \\ 5 Poultry Department, Faculty of Agriculture, Zagazig University, Zagazig 44511, Egypt; \\ dr.mohamed.e.abdalhaq@gmail.com (M.E.A.E.-H.); dr.mahmoud.alagwany@gmail.com (M.A.) \\ 6 Department of Poultry Production, Faculty of Agriculture (El-Shatby), Alexandria University, \\ Alexandria 22758, Egypt \\ * $\quad$ Correspondence: mfbadr@ksu.edu.sa (M.F.E.); kareem.badr@alexu.edu.eg (K.E.-S.)
}

Received: 29 December 2019; Accepted: 22 January 2020; Published: 4 February 2020

Simple Summary: The current study aimed to investigate the effects of a housing system, and dietary supplementation of rosemary and cinnamon essential oils on layers performance and egg quality. A factorial arrangement $(2 \times 3)$ was performed including two housing systems (floor and cage) and three different types of essential oils $(0,300 \mathrm{mg} / \mathrm{kg}$ diet of rosemary and $300 \mathrm{mg} / \mathrm{kg}$ diet of cinnamon essential oils) to study their effects on the productive performance, egg quality, immunity, oxidative stress and haematology of laying hens during the production stages. The data suggested that the supplementation of rosemary and cinnamon essential oils in laying hen diet showed significant positive effects on hen performance and egg production. Additionally, the different housing systems did not result in any positive or negative impact on these traits.

\begin{abstract}
Housing system and nutrition are non-genetic factors that can improve the well-being of animals to obtain higher quality products. A better understanding of how different housing systems and essential oils can influence the performance of layers is very important at the research and commercial levels. The current study aimed to investigate the effects of a housing system and dietary supplementation of rosemary and cinnamon essential oils on layers' performance and egg quality. A factorial arrangement $(2 \times 3)$ was performed include two housing systems (floor and cage) and three different types of essential oils $(0,300 \mathrm{mg} / \mathrm{kg}$ diet of rosemary and $300 \mathrm{mg} / \mathrm{kg}$ diet of cinnamon essential oils) to study their effects on the productive performance, egg quality, immunity, oxidative stress and haematology of ISA brown laying hens during the production stages (from 28 to 76 weeks of age). Birds were randomly divided into two groups each comprising of 1500 birds; the first group was moved from the litter to reared laying cages while the second group was floor reared. Each group was randomly divided into three groups, the first was considered as a control group, the second treated with rosemary essential oil, and the third with cinnamon essential oil. The differences in egg production and weight, egg quality, feed intake and conversion, blood picture and chemistry, immunity, and antioxidant parameters between the different housing systems (floor and cage) were
\end{abstract}


not significant at $(p<0.05$ or 0.01$)$. On the other hand, the egg production and weight, Haugh unit, feed intake and conversion, blood cholesterol, Alanine Aminotransferase (ALT), Aspartate Aminotransferase (AST), urea, Ca, P, immunity, and antioxidant parameters were significantly $(p<0.05$ or 0.01$)$ better in rosemary and cinnamon groups than in the control group. Furthermore, the results of dietary supplementation with rosemary and cinnamon were very close. Regarding egg production and weight, there were no significant differences due to the interactions. The differences in egg mass among the interactions were also not significant except at 68-76 weeks, where the cage $\times$ cinnamon group was the highest. Under the floor rearing system, birds that were fed a diet supplemented with or without essential oils (EOs) consumed more feed than those raised under the cage system. Regarding feed conversion rate (FCR), the differences among the interactions were not significant except at 44-52, 52-60 and 68-76 weeks, where the cage $\times$ cinnamon group was the lowest. Excluding glutathione peroxidase (GPx) activity $(p<0.001)$, all immunity and antioxidant indices were not statistically different as a consequence of the interaction among EOs and housing systems. Additionally, the highest levels of phosphorus were observed for layers fed diets enriched with cinnamon oil with the cage or floor system. In conclusion, the data suggested that supplementation of rosemary and cinnamon essential oils in laying hen diet showed significantly positive effects on hen performance and egg production. Cholesterol, liver and kidney functions, immunity, and antioxidant parameters improved with rosemary and cinnamon supplementation when compared to the control. Additionally, the different housing systems did not result in any positive or negative impact on these traits.

Keywords: antioxidant; essential oils; housing system; immunity; ISA brown; production

\section{Introduction}

Housing systems have always had an impact on animal welfare and performance [1-3]. Housing systems, as a non-genetic factor, can improve the well-being of animals to obtain higher quality products. A better understanding of how different housing systems can influence the performance of layers is required. The housing system could influence both the laying hen's performance and egg quality traits [4]. Englmaierová et al. [4] found that the highest egg production, lowest daily feed consumption, and feed conversion ratio were measured in cages compared to litter. Moreover, higher eggshell, yolk index, and albumen qualities were observed in cages. El-Deek and El-Sabrout [5] concluded that the maintenance of hens in enriched cages and with outdoor access would make it easier for the layers to express their natural behaviour, which has a favourable effect on their welfare and production. Additionally, consumers are recently interested in poultry products originating from alternative housing systems [6], which are natural, organic and have less content of substances that can endanger human health.

In recent decades, plants' oils have been used routinely in chicken farms for keeping chickens healthy and enhancing their productive performance because they contain active components which exert positive effects on physiological processes and have medicinal effects such as antibacterial, anti-inflammatory, and antioxidant [7-10]. There is a global trend in restricting the use of antibiotic growth promoters in the animal diet [11] and finding alternative solutions to maintain current animal production efficiency. Essential oils (EOs) have great potential among the alternatives and are generally regarded as safer and residue-free [12]. Due to their preventive and curative properties, species of the Labiatae family have enjoyed a rich tradition of flavoring and pharmaceutical use. Rosemary (Rosmarinus officinalis) is an herb that belongs to this family and has been recognized as the plant with the highest antioxidative activity [13]. Rosmarinic acid, camphor, and the antioxidants carnosic acid and carnosol are the most important organic chemicals, which have been already extracted from rosemary $[14,15]$. The supplementation of rosemary oil $(200 \mathrm{mg} / \mathrm{kg})$ in the laying hen's diet led to 
a significant improvement in feed conversion and an increase in the Haugh unit (key indicators of internal egg quality) of the egg as well as a larger egg weight [16]. It was also determined that rosemary oil exhibited higher antimicrobial activity than the control (commercial diet) by reducing the E. coli concentration in feces. Additionally, using rosemary as a natural antioxidant can decrease plasma total lipids when compared to the control, while LDL-cholesterol and total cholesterol can be insignificantly decreased [7]. Supplementation of 1\% rosemary can also improve feed conversion and decreased malonaldehyede (MDA) formation in egg yolk, and has been shown to have a positive impact on oxidative stability of eggshell storage [7]. Moreover, Alagawany and Abd El-Hack [17] concluded that rosemary supplemented up to $6 \mathrm{~g} / \mathrm{kg}$ diet can be used as an effective feed additive to improve performance, immunity and antioxidant status in laying hens.

On the other hand, cinnamon (Cinnamomum zeylanicum) is a common herb and is produced from the bark of the cinnamon tree. Cinnamon herb or its derivatives can serve as a hepatic stimulant by increasing bile secretion, removing toxins, and regulating hydration and can be used as a growth enhancer. Additionally, nutritional aspects of cinnamon powder or its derivatives include positive impacts regarding growth curve, digestion, absorption, activity of gut microbiota, immunity, as well as improved feed utilization and public health of poultry [18]. As a conclusion of Şimşek et al.'s [9] study, working on laying quails, cinnamon essential oil supplementation into a diet with a 200 ppm level increased egg production, eggshell quality, and improved the feed conversion ratio. On the other hand, rosemary supplementation with the same amount did not result in any positive or negative effects on egg production traits while the mixture of both of them had a negative effect on egg weight.

The data concerning the effect of different essential oils (rosemary and cinnamon) under different housing systems (floor and cage) on production, egg quality, immunity, haematology, blood biochemical and antioxidant parameters of layers are rare. Therefore, the objective of this research was to investigate the effects of a housing system, and the supplementation of rosemary and cinnamon essential oils on layers' performance, haematological traits, blood chemistry, immunity, egg quality, and antioxidants.

\section{Materials and Methods}

All procedures were implemented according to the Local Experimental Animal Care Committee and approved by the ethics of the institutional committee of Damanhour University, Egypt.

\subsection{Birds and Experimental Design}

Three thousand 27-week old ISA brown laying hens were obtained from Al Waha poultry industry (Damo-El Basyounia-El Fayoum-Egypt). A factorial arrangement $(2 \times 3)$ was performed, which included two housing systems and three different types of essential oils $(0,300 \mathrm{mg} / \mathrm{kg} \mathrm{diet}$ of rosemary and $300 \mathrm{mg} / \mathrm{kg}$ diet of cinnamon essential oils) to study their effects on the productive performance, egg quality, immunity, oxidative stress and haematology of laying hens during the production stages (from 28 to 76 weeks of age). Birds were randomly divided into two groups each comprising 1500 birds; the first group was moved to laying cages, while the second group was floor reared. Each group was randomly divided into three groups, the first were considered as a control group, the second treated with rosemary essential oil, and the third with cinnamon essential oil. Each group was divided into five equal replicates each of 100 birds. Rosemary essential oil was obtained from Quanao, Shaanxi, China; and cinnamon essential oil was obtained from YiSenYuan, Jiangxi, China (the purity of both oils was 100\%). The birds were housed in an open sided farm and each replicate of floor reared layers were housed in a separate pen of about $10 \mathrm{~m}^{2} \mathrm{space}$. The pens were separated by nets of $2 \mathrm{~m}$ height to avoid group mixing and to avoid interference with air movement, while caged birds in each replicate were housed in separate cages divided into pens, where each pen had dimensions of $40 \mathrm{~cm} \times 50 \mathrm{~cm} \times 40 \mathrm{~cm}$ suitable for five birds. The cage consisted of two levels, with each level containing 10 pens ( 5 on each side). 


\subsection{Dietary Treatments}

Composition of basal diet and their calculated analysis is presented in Table 1. The hens were fed diets in mash form during the experiment (28-76 weeks). The diets were formulated to meet or exceed NRC [19] recommendations.

Table 1. Ingredients and calculated analysis of layer basal diet.

\begin{tabular}{lc}
\multicolumn{1}{c}{ Item } & $\%$ \\
\hline Ingredients & \\
Yellow corn & 61.23 \\
Soybean meal (44\% protein) & 19.02 \\
Corn gluten meal (60\% protein) & 7.02 \\
Vitamins and minerals premix * & 0.30 \\
Wheat bran & 0.46 \\
Calcium carbonate & 1.36 \\
Di-calcium phosphate & 8.96 \\
DL-methionine & 0.05 \\
NaCl & 0.40 \\
Lysine & 1.20 \\
Chemical analysis (\%) $* *$ & \\
Crude protein & 18.01 \\
Metabolic energy (Kcal/kg) & 2800 \\
Crude fiber & 2.85 \\
Calcium & 3.81 \\
Phosphorus & 0.63 \\
\hline
\end{tabular}

* Each diet was supplied with $3 \mathrm{~kg} /$ ton Vitamins and Minerals Mix (commercial source B. p. Max) Each $3 \mathrm{~kg}$ contains, Vit. A 10,000,000 MIU, Vit. D 2,000,000 MIU, Vit. E 10,000 mg, Vit. K3 1000 mg, Vit. B1 1000 mg, Vit. B2 5000 mg, Vit. B6 $1500 \mathrm{mg}$, Biotin $50 \mathrm{mg}$, BHT 10,000 mg, Pantothenic 10,000 mg, folic acid $1000 \mathrm{mg}$, Nicotinic acid 30,000 mg $\mathrm{Mn} 60 \mathrm{~g}$, Zinc $50 \mathrm{~g}$, Fe $30 \mathrm{~g}, \mathrm{Cu} 4 \mathrm{~g}, \mathrm{I} 3 \mathrm{~g}$, Selenium $0.1 \mathrm{~g}$ and $\mathrm{Co} 0.1 \mathrm{~g}$. ${ }^{* *}$ The diets were formulated to meet or exceed NRC [19] recommendations.

\subsection{Estimation of Laying Performance Parameters and Egg Quality}

Hen-day egg production (HDEP), feed consumption and egg weight was recorded daily on a replicate basis. Feed intake was calculated by subtracting the remaining feed daily from the offered feed. Feed conversion ratio was calculated as grams of feed intake per gram of egg mass produced. Average egg mass (per hen per day in grams) $=\%$ HDEP $\times$ Average egg weight in grams. The parameters relative to egg quality were evaluated at 72 weeks of age. Fifteen eggs were randomly collected per treatment to determine these parameters. The collected eggs were weighed using a digital balance. On breaking, the egg contents were poured. The Haugh unit (HU) was measured for the internal quality of the eggs [20]. The height, correlated with the weight, determined the HU. The higher the number, the better the quality of the egg (fresher, higher quality eggs have thicker whites). Eggshell, albumin, and yolk percentages were also measured. Eggshell thickness (without the shell membrane) was measured from the middle part of the egg using a micrometer. Yolk index was calculated by formula: Yolk height/Yolk width $\times 100$; while the egg index was calculating using the following formula: (Egg width/egg length) $\times 100$.

\subsection{Estimation of Blood Haematological and Biochemical Parameters}

Blood samples $(n=25)$ were collected from each group as five samples from each replicate from the wing vein at 56 weeks of age. After collecting the blood samples, the tubes were left in the slope position until serum samples were separated through centrifugation at $3000 \mathrm{rpm}$ for $15 \mathrm{~min}$. Red blood cells (RBCs) and white blood cells (WBCs) counts were determined according to Stoskopf [21] using haemocytometer. Blood hemoglobin (HB) was assessed by cyanomta-hemoglobin method [22]. Packed cell volume (PCV) was carried out by using microhaematocrit capillary tubes centrifuged at 12,000 rpm for $5 \mathrm{~min}$. The reading was made with the aid of a microhaematocrit reader and expressed as the 
volume of erythrocytes per $100 \mathrm{~cm}^{3}$ according to Blaxhall and Daisley [23]. Differential leucocytic counts were defined using a blood film that was prepared according to the method described by Lucky [24]. Ten drops from May-Grunwald stain stock solution on a dry, unfixed smear were added to an equal amount of distilled water, then mixed and left for $1 \mathrm{~min}$ for staining. The dye was decanted without rinsing. Diluted Giemsa's solution (10 drops of the dye were added to $10 \mathrm{~mL}$ of distilled water) was poured over the film as a counter stain and left for $20 \mathrm{~min}$, then rinsed in water current and examined by oil immersion lens. The percentage and absolute value for each of the type of cells were calculated according to Schalm et al. [25]. The sera were collected and preserved in a deep freezer at $\left(-20^{\circ} \mathrm{C}\right)$ until the time of analysis. All the following studied parameters were calorimetrically evaluated. Estimation of blood cholesterol content was determined by cholesterol kit of Bio-diagnostic according to Richmond [26] and Allain et al. [27]. Total protein was determined by kits of Bio-diagnostic according to the method of Gornal et al. [28]. Alanine Aminotransferase (ALT) was determined by the ALT kit of Bio-diagnostic according to the method of Reitman and Frankel [29], while Aspartate Aminotransferase (AST) was determined by the AST kit of Bio-diagnostic according to the method of Retiman and Frankel [29]. Creatinine was defined according to the method of Bartles et al. [30], while urea was defined according to the method of Fawcett and Scott [31]. Calcium (Ca) and Phosphorus $(\mathrm{P})$ were measured spectrophotometrically by using commercial kits (Spectrum chemical company, PO. Box 30, Obour City-Cairo, Egypt).

\subsubsection{Estimation of Malondialdehyde, Glutathione Peroxidase and Super Oxide Dismutase}

Estimation of blood Malondialdehyde (MDA) concentration was measured by the method of Jo and Ahn [32]. Determination of Glutathione peroxidase (GPx) activity measured using the Paglia and Valentine [33] spectrophotometric method based on the Northwest Life Science Specialties (NWLSSTM) Glutathione peroxidase assay kits protocol NWK-GPX01. Determination of Super Oxide Dismutase (SOD) activity was assessed using the NWLSS ${ }^{\mathrm{TM}}$ Superoxide dismutase activity assay, which provided a simple, rate method for determining SOD activity. This method is based on monitoring the auto-oxidation rate of haematoxylin as originally described by Martin Jr. et al. [34].

\subsubsection{Estimation of Phagocytic Index, Phagocytic Activity and Cellular Immunity}

Blood and serum samples were collected at 56 days of age (five samples per replicate and total 25 samples per each group) as mentioned above according to Stott and Fellah [35] and used for the determination of Phagocytic activity and phagocytic index was determined according to Kawahara et al. [36]. Fifty micrograms of Candida albicans culture was added to $1 \mathrm{~mL}$ of citrated blood from each sample and incubated in a water bath at $25^{\circ} \mathrm{C}$ for five hours, and then blood smears from each tube were stained with Giemsa stain. Phagocytosis was estimated by determining the proportion of macrophages, which contained intracellular yeast cells in a random count of 300 macrophages and expressed as percentage of phagocytic activity (PA). The number of phagocytized organisms was counted in the phagocytic cells and called the phagocytic index (PI).

Phagocytic activity $(\mathrm{PA})=$ Percentage of phagocytic cells containing yeast cells .

Phagocytic index (PI) = Number of yeast cells phagocytized/Number of phagocytic cells.

\subsection{Statistical Analysis}

Data were analyzed by the statistical analysis system SAS [37]. A $2 \times 3$ factorial design was used to analyze data of performance as a response to two housing systems and three different types of essential oils. Differences among means were detected using two-way analysis of variance (ANOVA). The differences among means were determined using the Duncan test $(p<0.05)$. The model used was:

$$
Y_{i j}=\mu+D_{i}+A_{j}+D A_{i j}+e_{i j}
$$


where: $Y_{i j}=$ an observation, $\mu=$ the overall mean, $D_{i}=$ fixed effect of housing system, $A_{j}=$ fixed effect of essential oils, $\mathrm{DA}_{\mathrm{ij}}=$ fixed effect of interaction between housing system and essential oils and $\mathrm{e}_{\mathrm{ij}}=$ random error associated to each observation.

\section{Results and Discussion}

The effects of different housing systems, essential oils supplementations and their interaction on the egg production of laying hens is shown in Table 2. The differences in egg production percentages between the different housing systems (floor and cage) were not significant at $p<0.05$ or 0.01 . This finding was in agreement with the results of Zita et al. [38]. They indicated no effect of housing system on the egg production of hens. Egg production percentages were significantly $(p<0.05$ or 0.01 ) higher in the rosemary and cinnamon groups than in the control group, whereas there were no significant interactions. Şimşek et al. [9] found that cinnamon supplementation helped to increase the egg production. Moreover, Ding et al. [39] revealed that hen-day egg production was significantly improved $(p<0.05)$ at 58 to 61 weeks with the diet supplemented with essential oils Enviva commercial product $(50,100$, and $150 \mathrm{mg} / \mathrm{kg}$ ) including thymol $13.5 \%$ and cinnamaldehyde $4.5 \%$.

Table 2. Egg production of laying hens as affected by different housing systems, essential oils and their interaction during the experiment.

\begin{tabular}{|c|c|c|c|c|c|c|}
\hline \multirow{2}{*}{ Items } & \multicolumn{6}{|c|}{ Egg Production \% During } \\
\hline & 28-36 week & 36-44 week & 44-52 week & $52-60$ week & 60-68 week & 68-76 week \\
\hline \multicolumn{7}{|l|}{ Housing system } \\
\hline Cage & 87.86 & 88.89 & 85.12 & 79.76 & 71.99 & 62.60 \\
\hline Floor & 85.11 & 85.36 & 81.20 & 75.44 & 68.45 & 58.83 \\
\hline \multicolumn{7}{|c|}{ Essential oils (EOs) $^{1}$} \\
\hline 0 & $83.87^{b}$ & $84.68^{b}$ & $80.18^{b}$ & $73.06^{b}$ & $65.56^{b}$ & $56.00^{b}$ \\
\hline Rosemary EO & $88.30^{\mathrm{a}}$ & $88.95^{\mathrm{a}}$ & $85.40^{\mathrm{a}}$ & $80.15^{\mathrm{a}}$ & $72.25^{a}$ & $63.00^{\mathrm{a}}$ \\
\hline Cinnamon EO & $87.30^{\mathrm{a}}$ & $87.75^{\mathrm{a}}$ & $83.90^{a}$ & $79.60^{\mathrm{a}}$ & $72.85^{\mathrm{a}}$ & $63.15^{\mathrm{a}}$ \\
\hline SEM $^{2}$ & 0.705 & 1.142 & 1.412 & 1.373 & 1.287 & 0.927 \\
\hline \multicolumn{7}{|l|}{ Probability } \\
\hline Housing system & $<0.001$ & 0.001 & 0.004 & 0.001 & 0.004 & $<0.001$ \\
\hline EOs & $<0.001$ & 0.002 & 0.007 & $<0.001$ & $<0.001$ & $<0.001$ \\
\hline
\end{tabular}

The effects of different housing systems, essential oils supplementations and their interaction on egg weight of laying hens are shown in Table 3. The differences in egg weight between the different housing systems (floor and cage) were not significant at ( $p<0.05$ or 0.01 ). This finding was also in agreement with the results of Zita et al. [38]. The egg weights were significantly $(p<0.05$ or 0.01$)$ higher in rosemary and cinnamon groups than in the control group at 28-36 and 52-60 weeks while there were no significant interactions. The highest egg weight was found in the rosemary group at 44-52 weeks and 60-68 weeks. In agreement, Şimşek et al. [9] reported that the highest egg weight in quail was found in the rosemary group. On the other hand, Alagawany and Abd El-Hack [17] reported that there were no differences in egg weight due to adding rosemary to laying hens. Furthermore, Ding et al. [39] and Cufadar [40] reported that egg weight was not affected by the diet supplemented with essential oils. 
Table 3. Egg weight of laying hens as affected by different housing systems, essential oils and their interaction during the experiment.

\begin{tabular}{|c|c|c|c|c|c|c|}
\hline \multirow{2}{*}{ Items } & \multicolumn{6}{|c|}{ Egg Weight (g) During } \\
\hline & 28-36 week & 36-44 week & 44-52 week & 52-60 week & 60-68 week & 68-76 week \\
\hline \multicolumn{7}{|l|}{ Housing system } \\
\hline Cage & 45.52 & 51.03 & 55.27 & 57.93 & 59.24 & 60.35 \\
\hline Floor & 43.90 & 50.69 & 55.15 & 57.11 & 58.65 & 59.82 \\
\hline \multicolumn{7}{|c|}{ Essential oils (EOs) $^{1}$} \\
\hline 0 & $41.93^{b}$ & 49.93 & $54.75^{\mathrm{b}}$ & $56.12^{b}$ & $57.93^{b}$ & 59.06 \\
\hline Rosemary EO & $46.00^{\mathrm{a}}$ & 51.95 & $56.80^{\mathrm{a}}$ & $58.70^{\mathrm{a}}$ & $59.70^{a}$ & 60.80 \\
\hline Cinnamon EO & $46.20^{\mathrm{a}}$ & 50.70 & $54.10^{\mathrm{b}}$ & $57.75^{\mathrm{a}}$ & $59.20^{a b}$ & 60.40 \\
\hline SEM $^{2}$ & 0.827 & 0.529 & 0.529 & 0.561 & 0.502 & 0.722 \\
\hline \multicolumn{7}{|l|}{ Probability } \\
\hline Housing system & 0.015 & 0.632 & 0.844 & 0.083 & 0.180 & 0.349 \\
\hline EOs & $<0.001$ & 0.086 & 0.002 & 0.001 & 0.010 & 0.050 \\
\hline
\end{tabular}

The effects of different housing systems, essential oils supplementations and their interaction on egg mass of laying hens are shown in Table 4 . The differences in egg mass between the different housing systems (floor and cage) were not significant at $(p<0.05$ or 0.01 ). The egg masses were significantly $(p<0.05$ or 0.01$)$ higher in rosemary and cinnamon groups than in the control group at 28-36, 44-52, 52-60, 60-68 and 68-76 weeks, while the differences among the interactions were not significant except at $68-76$ weeks, and the cage $\times$ cinnamon group was the highest. In agreement, Alagawany and Abd El-Hack [17] reported that egg mass linearly increased with rosemary supplementation, while Cufadar [40] indicated that there were no differences in egg mass due to the addition of rosemary in laying hen diet.

Table 4. Egg mass of laying hens as affected by different housing systems, essential oils and their interaction during the experiment.

\begin{tabular}{|c|c|c|c|c|c|c|c|}
\hline \multirow{2}{*}{\multicolumn{2}{|c|}{ Items }} & \multicolumn{6}{|c|}{ Egg Mass (g) During } \\
\hline & & 28-36 week & 36-44 week & 44-52 week & 52-60 week & 60-68 week & 68-76 week \\
\hline \multicolumn{8}{|l|}{ Housing system } \\
\hline & Cage & 43.60 & 46.26 & 47.14 & 44.69 & 40.13 & 18.35 \\
\hline & Floor & 40.61 & 44.74 & 43.90 & 41.83 & 37.87 & 16.94 \\
\hline \multicolumn{8}{|c|}{ Essential oils (EOs) $^{1}$} \\
\hline & 0 & $38.56^{\mathrm{b}}$ & $44.31^{\mathrm{b}}$ & $42.15^{\mathrm{b}}$ & $39.66^{\mathrm{b}}$ & $35.68^{b}$ & $15.89^{\mathrm{b}}$ \\
\hline & Rosemary EO & $44.35^{\mathrm{a}}$ & $47.32^{\mathrm{a}}$ & $48.32^{a}$ & $45.30^{\mathrm{a}}$ & $40.52^{a}$ & $18.69^{\mathrm{a}}$ \\
\hline & Cinnamon EO & $43.41^{\mathrm{a}}$ & $44.86^{\mathrm{b}}$ & $46.08^{a}$ & $44.82^{\mathrm{a}}$ & $40.80^{\mathrm{a}}$ & $18.36^{\mathrm{a}}$ \\
\hline \multicolumn{8}{|l|}{ Housing $\times$ EOs } \\
\hline \multirow{3}{*}{ Cage } & 0 & 39.76 & 45.78 & 44.60 & 41.31 & 36.69 & $16.88^{\mathrm{c}}$ \\
\hline & Rosemary EO & 45.69 & 47.36 & 49.52 & 46.04 & 41.20 & $18.78^{a b}$ \\
\hline & Cinnamon EO & 45.37 & 45.64 & 47.30 & 46.72 & 42.49 & $19.40^{\mathrm{a}}$ \\
\hline \multirow{3}{*}{ Floor } & 0 & 37.35 & 42.85 & 39.71 & 38.02 & 34.66 & $14.90^{\mathrm{d}}$ \\
\hline & Rosemary EO & 43.02 & 47.27 & 47.12 & 44.56 & 39.85 & $18.59^{a b}$ \\
\hline & Cinnamon EO & 41.46 & 44.09 & 44.87 & 42.92 & 39.10 & $17.32^{b}$ \\
\hline SEM $^{2}$ & & 0.829 & 0.856 & 0.980 & 0.837 & 0.760 & 0.300 \\
\hline \multicolumn{8}{|l|}{ Probability } \\
\hline Housing system & & $<0.001$ & 0.048 & 0.001 & 0.001 & 0.002 & $<0.001$ \\
\hline EOs & & $<0.001$ & $<0.006$ & $<0.001$ & $<0.001$ & $<0.001$ & $<0.001$ \\
\hline Housing $\times$ EOs & & 0.650 & 0.310 & 0.416 & 0.368 & 0.407 & 0.008 \\
\hline
\end{tabular}


The effects of different housing systems, essential oils supplementations and their interaction on feed intake of laying hens are shown in Table 5. The differences in feed intake between the different housing systems (floor and cage) were not significant at $p<0.05$ or 0.01 . The feed intakes were significantly ( $p<0.05$ or 0.01 ) lower in the rosemary and cinnamon groups than in the control group at 60-68 and 68-76 weeks. Apart from feed intake at 44-52 weeks, there were no significant differences due to the interaction effect between EOs and housing system. Under the floor system, birds fed diet supplemented with or without EOs consumed more feed (127.40 to $128.62 \mathrm{~g}$ ) than those raised under the cage system (119.50 to $124.60 \mathrm{~g}$ ). Feed intake was found to be similar between the rosemary and cinnamon groups as mentioned before by Şimşek et al. [9]. Although, essential oils are perceived as growth promoters in poultry diets [41], recent studies on poultry feeding intakes [42,43] have indicated that dietary incorporation of essential oils did not significantly affect the bird feed intake or they could decrease it insignificantly. However, there is a possible explanation for the reduced intake of feed is the irritating scent of essential oils, which makes the diet unpleasant to birds.

Table 5. Feed intake (g) of laying hens as affected by different housing systems, essential oils and their interaction during the experiment.

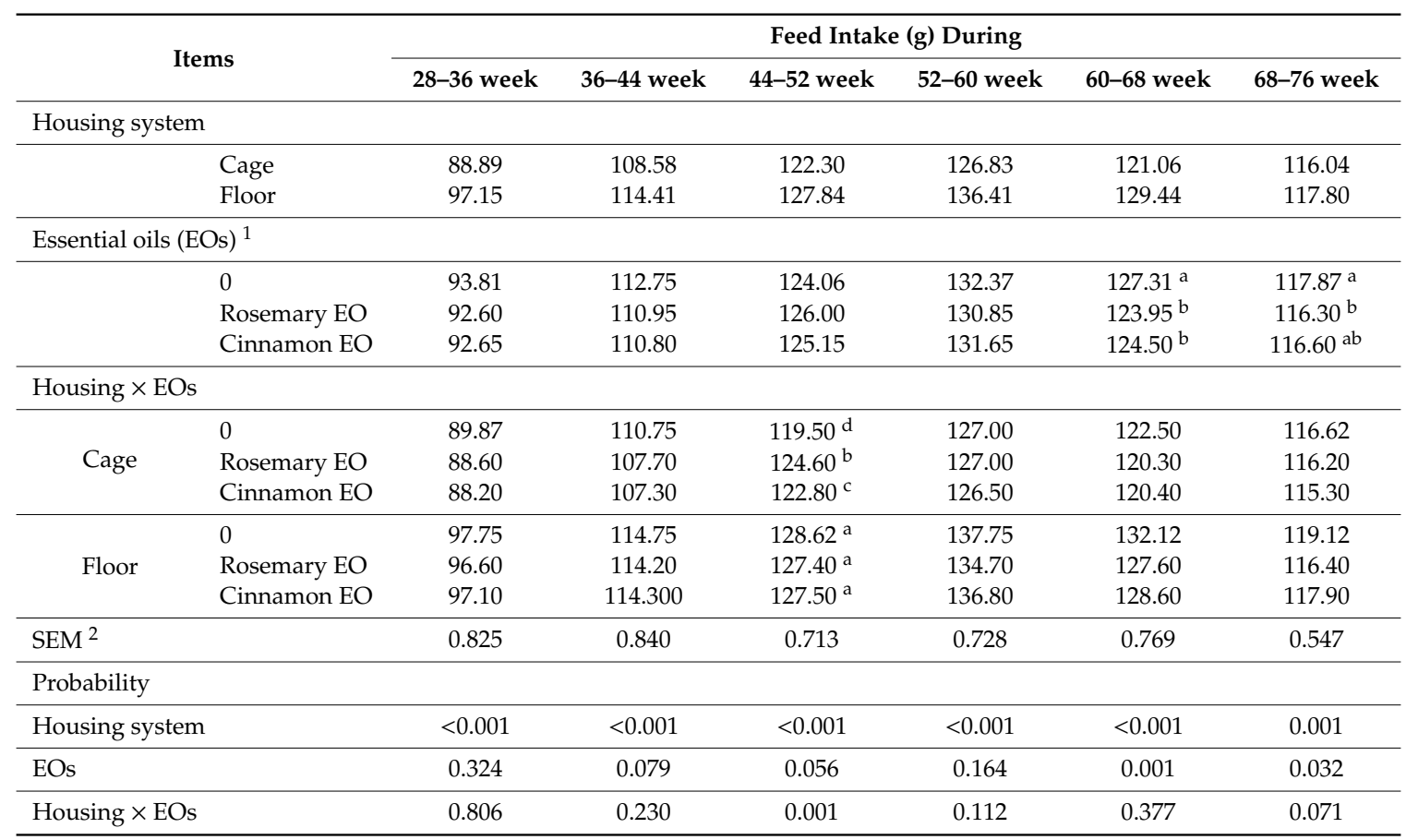

Means in the same column within each classification bearing different letters are significantly different. $(p<0.05$ or 0.01). ${ }^{1}$ EOs: Essential oils, EO: Essential oil. ${ }^{2}$ SEM: standard error mean.

The effects of different housing systems, essential oils supplementations and their interaction on feed conversion of laying hens are shown in Table 6. The differences in feed conversion between the different housing systems (floor and cage) were not significant at $p<0.05$ or 0.01 . The feed conversions were significantly ( $p<0.05$ or 0.01 ) lower in the rosemary and cinnamon groups than in the control group at 28-36, 36-44, 52-60, 60-68 and 68-76 weeks, while the differences among the interactions were not significant at ( $p<0.05$ or 0.01 ) except at $44-52,52-60$, and 68-76 weeks, with the lowest rates being observed for layers fed diets enriched with EOs in the cage. The cage $\times$ rosemary group achieved the best values of FCR at 44-52 and 52-60 weeks; while at 68-76 weeks, the best value was recorded by the cage $\times$ cinnamon group. It can be concluded that the interactions among cage and EOs system achieved the good results for the FCR in comparison with the floor system. Şimşek et al. [9] found that the best feed conversion was obtained in the cinnamon group. Ding et al. [39] reported that the hen feed conversion ratio was significantly improved $(p<0.05)$ at 58 to 61 weeks with the diet supplemented with essential oils. On the other hand, Alagawany and Abd El-Hack [17] reported that 
there were no differences in the feed consumption and feed conversion ratio due to adding rosemary to laying hens. However, there are two acceptable mechanisms to understand the effect of these essential oils. The first one considers the promotion of digestive enzyme secretion, and the second deals with the gut microflora ecosystem stabilization, leading to enhanced utilization of food and decreased exposure to growth-depressing disorders that could be related to the metabolism and the digestion processes [44-46]. Several chicken studies have documented positive effects of essential oils on the digestive enzyme (pancreatic $\alpha$-amylase and intestinal maltase) secretion and intestinal mucosa [47,48]. In broilers, the ileal activity of trypsin and chymotrypsin was significantly increased in the thymol group at day 21 compared with the control group [49]. In the in vitro study, Mathlouthi et al. [50] stated that rosemary essential oils had different antimicrobial impacts against pathogenic microbes however, had the same effect on avilamycin as a growth promoter when added to broiler rations. Furthermore, the latter authors found that in vivo growth promotion effects were due to the alterations in the gut microbiota rather than antimicrobial activities against a single bacterial species and genus. Decreased microbes in the gastrointestinal tract may enhance the proliferation ability of epithelial cells and thus improve intestinal absorptive capacity [51]. These effects have been confirmed by increased nutrient digestibility, however, this has not resulted in improved growth performance [52,53].

Table 6. Feed conversion of laying hens as affected by different housing systems, essential oils and their interaction during the experiment.

\begin{tabular}{|c|c|c|c|c|c|c|c|}
\hline \multirow{2}{*}{\multicolumn{2}{|c|}{ Items }} & \multicolumn{6}{|c|}{ Feed Conversion (g Feed/g Egg) During } \\
\hline & & \multirow[t]{2}{*}{ 28-36 week } & \multirow[t]{2}{*}{ 36-44 week } & \multirow[t]{2}{*}{ 44-52 week } & \multirow[t]{2}{*}{ 52-60 week } & \multirow[t]{2}{*}{$60-68$ week } & \multirow[t]{2}{*}{ 68-76 week } \\
\hline Housing sy & & & & & & & \\
\hline & Cage & 2.23 & 2.39 & 2.60 & 2.75 & 2.85 & 3.08 \\
\hline & Floor & 2.60 & 2.65 & 2.87 & 3.18 & 3.24 & 3.37 \\
\hline \multicolumn{8}{|c|}{ Essential oils (EOs) ${ }^{1}$} \\
\hline & 0 & $2.67^{\mathrm{a}}$ & $2.67^{\mathrm{a}}$ & $2.84^{\mathrm{a}}$ & $3.24^{\mathrm{a}}$ & $3.36^{\mathrm{a}}$ & $3.58^{a}$ \\
\hline & Rosemary EO & $2.28^{b}$ & $2.40^{b}$ & $2.60^{b}$ & $2.79^{b}$ & $2.88^{b}$ & $3.04^{b}$ \\
\hline & Cinnamon EO & $2.30^{b}$ & $2.49^{b}$ & $2.76^{\mathrm{a}}$ & $2.87^{\mathrm{b}}$ & $2.89^{b}$ & $3.07^{\mathrm{b}}$ \\
\hline \multicolumn{8}{|c|}{ Housing $\times$ EOs } \\
\hline \multirow{3}{*}{ Cage } & 0 & 2.48 & 2.52 & $2.61^{b}$ & $2.94^{\mathrm{a}}$ & 3.13 & $3.37^{\mathrm{b}}$ \\
\hline & Rosemary EO & 2.12 & 2.30 & $2.54^{\mathrm{c}}$ & $2.65^{b}$ & 2.76 & $3.00^{\mathrm{cd}}$ \\
\hline & Cinnamon EO & 2.09 & 2.36 & $2.65^{b c}$ & $2.66^{\mathrm{b}}$ & 2.67 & $2.88^{\mathrm{d}}$ \\
\hline \multirow{3}{*}{ Floor } & 0 & 2.86 & 2.82 & $3.06^{\mathrm{a}}$ & $3.55^{\mathrm{a}}$ & 3.59 & $3.79^{a}$ \\
\hline & Rosemary EO & 2.44 & 2.50 & $2.67^{b}$ & $2.93^{\mathrm{a}}$ & 3.01 & $3.07^{\mathrm{c}}$ \\
\hline & Cinnamon EO & 2.52 & 2.63 & $2.87^{b}$ & $3.07^{\mathrm{a}}$ & 3.12 & $3.25^{b}$ \\
\hline SEM $^{2}$ & & 0.035 & 0.046 & 0.055 & 0.058 & 0.056 & 0.058 \\
\hline \multicolumn{8}{|c|}{ Probability } \\
\hline Housing sy & & $<0.001$ & $<0.001$ & $<0.001$ & $<0.001$ & $<0.001$ & $<0.001$ \\
\hline EOs & & $<0.001$ & $<0.001$ & 0.002 & $<0.001$ & $<0.001$ & $<0.001$ \\
\hline Housing $x$ & & 0.291 & 0.569 & 0.036 & 0.040 & 0.147 & 0.014 \\
\hline
\end{tabular}

Means in the same column within each classification bearing different letters are significantly different. $(p<0.05$ or 0.01). ${ }^{1}$ EOs: Essential oils, EO: Essential oil. ${ }^{2}$ SEM: standard error mean.

The effects of different housing systems, essential oils supplementations and their interaction on egg quality of laying hens are shown in Table 7. The differences in egg quality traits between the different housing systems (floor and cage) were not significant at $p<0.05$ or 0.01 . In contrast, Tumova and Ebeid [54] found that the egg quality characteristics were better in eggs produced in cages when compared to alternative systems, and eggs produced from cage systems had higher values of Haugh units, albumen and yolk indices. Furthermore, higher eggshell and albumen qualities were observed in conventional cages by Englmaierová et al. [4]. The differences between the study's results could be due to differences in the strain used or the environmental conditions surrounding it (such as cages indoors or outdoors), as well as differences in the cages design. However, the differences in shell thickness among the different essential oil groups (including the control group) were also not significant 
$(p<0.05$ or 0.01$)$. On the other hand, Cufadar [40] reported that eggshell thickness was significantly increased with rosemary essential oil supplementation $(250 \mathrm{mg} / \mathrm{kg})$ in the diet of NOVOgen White laying hens. In general, Ding et al. [39] reported that eggshell thickness was significantly increased at 65 weeks with the diet supplemented with essential oils. Haugh unit scores were higher in rosemary and cinnamon groups than in the control group, while the control group was the highest in yolk index among the interactions at $p<0.05$ or 0.01 . It means that rosemary and cinnamon supplementation $(0.3 \mathrm{~g} / \mathrm{kg})$ decreased the egg yolk index for Isa Brown laying hens. On the other hand, Alagawany and Abd El-Hack [17] found that adding rosemary (up $6 \mathrm{~g} / \mathrm{kg}$ ) to Hi-sex Brown laying hen' diets resulted in a linear increase in yolk percent and yolk-to-albumen ratio. While, Botsoglou et al. [55] indicated that diets supplemented with rosemary oil $(5 \mathrm{~g} / \mathrm{kg})$ for Lohmann laying hens had no effects on the yolk index neither Haugh units. These conflicting results may be due to the different supplementation ratio or/and the strain used. Furthermore, Ding et al. [39] reported that Haugh units, generally, were not affected by the diet supplemented with essential oils.

Table 7. Egg quality of laying hens as affected by different housing systems, essential oils and their interaction during the experiment.

\begin{tabular}{|c|c|c|c|c|c|c|c|c|}
\hline & Items & $\begin{array}{l}\text { Shell Thickness } \\
\qquad(\mu \mathrm{m})\end{array}$ & $\begin{array}{c}\text { Eggshell } \\
\%\end{array}$ & Yolk \% & $\begin{array}{l}\text { Albumin } \\
\%\end{array}$ & $\begin{array}{l}\text { Egg } \\
\text { Index }\end{array}$ & $\begin{array}{l}\text { Yolk } \\
\text { Index }\end{array}$ & $\begin{array}{c}\text { Haugh } \\
\text { Unit }\end{array}$ \\
\hline \multicolumn{9}{|c|}{ Housing system } \\
\hline & Cage & 0.36 & 8.79 & 28.80 & 62.39 & 77.34 & 22.54 & 82.53 \\
\hline & Floor & 0.35 & 8.50 & 28.62 & 62.86 & 76.49 & 22.65 & 80.99 \\
\hline \multicolumn{9}{|c|}{ Essential oils (EOs) $^{1}$} \\
\hline & 0 & 0.35 & 8.54 & $28.49^{b}$ & $62.96^{\mathrm{a}}$ & $75.56^{c}$ & $23.55^{\mathrm{a}}$ & $79.55^{c}$ \\
\hline & Rosemary EO & 0.35 & 8.70 & $28.90^{\mathrm{a}}$ & $62.39^{b}$ & $77.34^{\mathrm{b}}$ & $22.17^{\mathrm{b}}$ & $82.40^{a}$ \\
\hline & Cinnamon EO & 0.36 & 8.71 & $28.75^{\mathrm{ab}}$ & $62.52^{b}$ & $77.84^{\mathrm{a}}$ & $22.07^{b}$ & $83.33^{a}$ \\
\hline \multicolumn{9}{|c|}{ Housing $\times$ EOs } \\
\hline \multirow{3}{*}{ Cage } & 0 & 0.36 & 8.77 & 28.56 & 62.66 & 76.10 & $23.33^{a}$ & 80.50 \\
\hline & Rosemary EO & 0.37 & 8.83 & 29.07 & 62.09 & 77.84 & $22.29^{b}$ & 83.27 \\
\hline & Cinnamon EO & 0.37 & 8.78 & 28.79 & 62.42 & 78.08 & $22.02^{b}$ & 83.82 \\
\hline \multirow{3}{*}{ Floor } & 0 & 0.35 & 8.30 & 28.41 & 63.27 & 75.03 & $23.78^{a}$ & 78.61 \\
\hline & Rosemary EO & 0.34 & 8.56 & 28.73 & 62.70 & 76.84 & $22.05^{b}$ & 81.52 \\
\hline & Cinnamon EO & 0.36 & 8.64 & 28.72 & 62.63 & 77.60 & $22.14^{\mathrm{b}}$ & 82.85 \\
\hline SEM $^{2}$ & & 0.091 & 0.801 & 0.110 & 0.134 & 0.177 & 0.121 & 0.416 \\
\hline \multicolumn{9}{|c|}{ Probability } \\
\hline \multicolumn{2}{|c|}{ Housing system } & 0.025 & $<0.001$ & 0.059 & $<0.001$ & $<0.001$ & 0.275 & $<0.001$ \\
\hline \multicolumn{2}{|l|}{ EOs } & 0.480 & 0.099 & 0.007 & 0.002 & $<0.001$ & $<0.001$ & $<0.001$ \\
\hline \multicolumn{2}{|c|}{ Housing $\times$ EOs } & 0.378 & 0.178 & 0.465 & 0.252 & 0.233 & 0.041 & 0.519 \\
\hline
\end{tabular}

Means in the same column within each classification bearing different letters are significantly different $(p<0.05$ or 0.01). ${ }^{1}$ EOs: Essential oils, EO: Essential oil. ${ }^{2}$ SEM: standard error mean.

The effects of different housing systems, essential oils supplementations and their interaction on the blood picture (haematological traits) of laying hens are shown in Table 8. The differences in blood picture between the different housing systems (floor and cage) and among the different essential oils groups were not significant at $p<0.05$ or 0.01 except in some differential WBCs (basophils; lymphocytes and monocytes \%). 
Table 8. Blood picture of laying hens as affected by different housing systems, essential oils and their interaction during the experiment.

\begin{tabular}{|c|c|c|c|c|c|c|c|c|c|c|}
\hline \multicolumn{2}{|c|}{ Items 1} & $\begin{array}{c}\text { WBC }(\times \\
\left.10^{3} / \mathrm{mm}^{3}\right)\end{array}$ & $\begin{array}{c}\text { RBC ( } \times \\
\left.10^{6} / \mathrm{mm}^{3}\right)\end{array}$ & $\begin{array}{c}\mathrm{PCV} \\
\%\end{array}$ & НВ \% & $\begin{array}{c}\text { Eosino } \\
\%\end{array}$ & $\begin{array}{c}\text { Lympho } \\
\%\end{array}$ & $\begin{array}{c}\text { Hetero } \\
\%\end{array}$ & $\begin{array}{c}\text { Baso } \\
\%\end{array}$ & $\begin{array}{c}\text { Mono } \\
\%\end{array}$ \\
\hline \multicolumn{11}{|c|}{ Housing system } \\
\hline \multicolumn{2}{|l|}{ Cage } & 23.78 & 3.21 & 29.17 & 14.14 & 8.33 & 35.71 & 23.43 & 1.08 & 5.36 \\
\hline \multicolumn{2}{|l|}{ Floor } & 23.86 & 3.22 & 29.16 & 14.19 & 8.38 & 35.88 & 23.54 & 1.08 & 5.35 \\
\hline \multicolumn{11}{|c|}{ Essential oils (EOs) ${ }^{2}$} \\
\hline \multicolumn{2}{|l|}{0} & 23.77 & 3.19 & 29.12 & 14.11 & 8.28 & $35.13^{b}$ & 23.38 & $1.05^{\mathrm{b}}$ & $5.21^{\mathrm{b}}$ \\
\hline \multicolumn{2}{|c|}{ Ros EO } & 23.93 & 3.22 & 29.08 & 14.22 & 8.34 & $35.93^{a b}$ & 23.63 & $1.10^{\mathrm{a}}$ & $5.41^{\mathrm{ab}}$ \\
\hline \multicolumn{2}{|c|}{ Cinn EO } & 23.76 & 3.22 & 29.29 & 14.17 & 8.44 & $36.33^{a}$ & 23.45 & $1.09^{\mathrm{a}}$ & $5.46^{\mathrm{a}}$ \\
\hline \multicolumn{11}{|c|}{ Housing $\times$ EOs } \\
\hline \multirow{3}{*}{ Cage } & 0 & 23.77 & $3.22^{a}$ & 29.07 & 14.10 & 8.35 & 35.60 & 23.37 & $1.07^{\mathrm{b}}$ & 5.30 \\
\hline & Ros EO & 23.88 & $3.21^{\mathrm{a}}$ & 29.16 & 14.24 & 8.26 & 35.58 & 23.50 & $1.08^{b}$ & 5.38 \\
\hline & Cinn EO & 23.70 & $3.20^{\mathrm{a}}$ & 29.28 & 14.08 & 8.38 & 35.96 & 23.42 & $1.08^{b}$ & 5.42 \\
\hline \multirow{3}{*}{ Floor } & 0 & 23.77 & $3.17^{b}$ & 29.17 & 14.12 & 8.22 & 34.67 & 23.40 & $1.02^{b}$ & 5.12 \\
\hline & Ros EO & 23.99 & $3.23^{\mathrm{a}}$ & 29.00 & 14.20 & 8.42 & 36.28 & 23.76 & $1.11^{\mathrm{a}}$ & 5.44 \\
\hline & Cinn EO & 23.81 & $3.25^{\mathrm{a}}$ & 29.314 & 14.26 & 8.50 & 36.70 & 23.48 & $1.10^{\mathrm{a}}$ & 5.50 \\
\hline \multicolumn{2}{|l|}{ SEM $^{3}$} & 0.108 & 0.016 & 0.145 & 0.078 & 0.085 & 0.364 & 0.140 & 0.013 & 0.088 \\
\hline \multicolumn{11}{|c|}{ Probability } \\
\hline \multicolumn{2}{|c|}{ Housing system } & 0.377 & 0.432 & 0.932 & 0.437 & 0.479 & 0.585 & 0.293 & 0.966 & 0.853 \\
\hline \multicolumn{2}{|l|}{ EOs } & 0.173 & 0.222 & 0.237 & 0.422 & 0.236 & 0.018 & 0.178 & 0.006 & 0.018 \\
\hline \multicolumn{2}{|c|}{ Housing $\times$ EOs } & 0.840 & 0.029 & 0.605 & 0.360 & 0.260 & 0.075 & 0.624 & 0.030 & 0.260 \\
\hline
\end{tabular}

Means in the same column within each classification bearing different letters are significantly different $(p<0.05$ or 0.01). ${ }^{1}$ WBC: White blood cells, RBC: Red blood cells, PCV: Packed cell volume, HB: Hemoglobin, Eosino: Eosinophils, Lympho: Lymphocytes, Heter: Heterophils, Baso: Basophils, Mono: Monocytes. ${ }^{2}$ EOs: Essential oils,

Ros EO: Rosemary essential oil, Cinn EO: Cinnamon essential oil. ${ }^{3}$ SEM: Standard error mean.

The effects of different housing systems, essential oils supplementations and their interaction on immunity and antioxidant parameters of laying hens are shown in Table 9. The differences in immunity and antioxidant parameters between the different housing systems (floor and cage) were not significant at $p<0.05$ or 0.01 while among the different essential oils groups, they were significant in $\mathrm{ND}, \mathrm{AI}$ H5, AI H9, MDA, and SOD. Excluding GPx activity $(p<0.001)$, all immunity and antioxidant indices were not statistically different as a consequence of the interaction among housing systems and EOs. The interaction between floor and basal diet gave the highest $(26.25 \mathrm{U} / \mathrm{gHb})$ activity of GPx in comparison with the other interactions. However, the lowest value $(15.00 \mathrm{U} / \mathrm{gHb})$ was found in birds fed with a control diet with the cage system.

In general, some designs of housing systems can cause some stress on hens. This stress can play an effective role in the bird's immune system resulting in failure of vaccination or increased disease during production [56,57]. However, essential oils are a total of volatile constituents, and therefore the effects of essential oils could be a complete product of all components and their interactions. Two or three components can account for up to $85 \%$ of the total mixture, and thereby contribute to the primary property of the essential oil mixture [58]. For example, phenols (thymol and carvacrol) account for more than $70 \%$ of plant essential oils and are primarily responsible for their antibacterial and antioxidant functions. Rosemary has been recognized as the plant with the highest anti-oxidative activity [13]. On the other hand, cinnamon or its oil play an important role in improving the growth, production, digestion, absorption, activity of gut microbiota, immunity, as well as feed utilization and public health of poultry [18]. 
Table 9. Immunity and antioxidant parameters of laying hens as affected by different housing systems, essential oils and their interaction during the experiment.

\begin{tabular}{|c|c|c|c|c|c|c|c|c|c|}
\hline \multicolumn{2}{|c|}{ Items $^{1}$} & $\begin{array}{l}\text { Phagocytic } \\
\text { Index }\end{array}$ & $\begin{array}{l}\text { Phagocytic } \\
\text { Activity }\end{array}$ & $\begin{array}{l}\text { ND } 60 \\
\text { W }\end{array}$ & $\begin{array}{l}\text { AI H5 } \\
60 \mathrm{~W}\end{array}$ & $\begin{array}{c}\text { AI H9 } \\
60 \mathrm{~W}\end{array}$ & $\begin{array}{c}\text { MDA } \\
\text { (nmoles } / \mathrm{mL} \text { ) }\end{array}$ & $\begin{array}{c}\text { GPx } \\
\text { (U/gHb) }\end{array}$ & $\begin{array}{l}\text { SOD } \\
(\mathrm{U} / \mathrm{gHb})\end{array}$ \\
\hline \multicolumn{10}{|c|}{ Housing system } \\
\hline \multicolumn{2}{|l|}{ Cage } & 1.62 & 16.35 & 2.89 & 2.75 & 2.62 & 2.13 & 18.26 & 72.38 \\
\hline \multicolumn{2}{|l|}{ Floor } & 1.63 & 16.24 & 2.75 & 2.61 & 2.55 & 2.31 & 22.63 & 75.15 \\
\hline \multicolumn{10}{|c|}{ Essential oils (EOs) $^{2}$} \\
\hline \multicolumn{2}{|l|}{0} & 1.53 & 15.75 & $2.63^{b}$ & $2.36^{\mathrm{b}}$ & $2.22^{b}$ & $2.50^{\mathrm{a}}$ & 20.62 & $81.00^{\mathrm{a}}$ \\
\hline \multicolumn{2}{|l|}{ Ros EO } & 1.66 & 16.45 & $2.86^{\mathrm{a}}$ & $2.78^{a}$ & $2.68^{a}$ & $2.21^{\mathrm{b}}$ & 20.80 & $73.70^{\mathrm{b}}$ \\
\hline \multicolumn{2}{|c|}{ Cinn EO } & 1.69 & 16.70 & $2.97^{\mathrm{a}}$ & $2.89^{a}$ & $2.86^{\mathrm{a}}$ & $1.97^{\mathrm{c}}$ & 20.00 & $66.60^{\mathrm{c}}$ \\
\hline \multicolumn{10}{|c|}{ Housing $\times$ EOs } \\
\hline \multirow{3}{*}{ Cage } & 0 & 1.57 & 16.37 & 2.82 & 2.49 & 2.33 & 2.45 & $15.00^{c}$ & 77.75 \\
\hline & Ros EO & 1.62 & 16.20 & 2.86 & 2.86 & 2.68 & 2.10 & $20.60^{b}$ & 74.00 \\
\hline & Cinn EO & 1.68 & 16.50 & 2.99 & 2.89 & 2.86 & 1.86 & $19.20^{\mathrm{b}}$ & 65.40 \\
\hline \multirow{3}{*}{ Floor } & 0 & 1.50 & 15.12 & 2.44 & 2.23 & 2.12 & 2.55 & $26.25^{a}$ & 84.25 \\
\hline & Ros EO & 1.70 & 16.70 & 2.86 & 2.71 & 2.68 & 2.32 & $21.00^{\mathrm{b}}$ & 73.40 \\
\hline & Cinn EO & 1.70 & 16.90 & 2.96 & 2.89 & 2.86 & 2.08 & $20.80^{b}$ & 67.80 \\
\hline \multicolumn{2}{|l|}{$\mathrm{SEM}^{3}$} & 0.072 & 0.47 & 0.095 & 0.085 & 0.081 & 0.070 & 0.882 & 2.15 \\
\hline \multicolumn{10}{|c|}{ Probability } \\
\hline \multicolumn{2}{|c|}{ Housing system } & 0.892 & 0.752 & 0.070 & 0.072 & 0.304 & 0.007 & $<0.001$ & 0.145 \\
\hline \multicolumn{2}{|l|}{ EOs } & 0.135 & 0.125 & 0.004 & $<0.001$ & $<0.001$ & $<0.001$ & 0.644 & $<0.001$ \\
\hline \multicolumn{2}{|c|}{ Housing $\times$ EOs } & 0.600 & 0.128 & 0.093 & 0.366 & 0.384 & 0.669 & $<0.001$ & 0.318 \\
\hline
\end{tabular}

Means in the same column within each classification bearing different letters are significantly different $(p<0.05$ or 0.01). ${ }^{1}$ ND: Newcastle disease, AI H5: Avian influenza H5, AI H9: Avian influenza H9, MDA: Malondialdehyde, GPX: Glutathione peroxidase, SOD: Superoxide dismutase. ${ }^{2}$ EOs: Essential oils, Ros EO: Rosemary essential oil, Cinn EO: Cinnamon essential oil. ${ }^{3}$ SEM: Standard error mean.

Through supplementing essential oils, a bird's anti-oxidative stability can be enhanced [12]. Placha et al. [59] found that malondialdehyde concentration in the liver and kidney was significantly reduced by the supplementation of essential oils to bird diet. Moreover, Lee et al. [60] and Khan et al. [61] reported that thyme essential oil had a significant effect on avian-derived products (meat and eggs) retarding oxidant degradation. Antioxidant activity could be derived from the phenolic $\mathrm{OH}$ group, which acts as a hydrogen donor interacting with peroxy radicals during the initial process of lipid oxidation and thereby inhibiting the formation of hydroxyl peroxide [60]. The antioxidant effect differs from plant essential oil to others depending on the amount of total phenols in it. With its successful antioxidant activities in broiler meat, rosemary has been identified [62,63].

The effects of different housing systems, essential oils supplementations and their interaction on the blood chemistry of laying hens are shown in Table 10.

The differences in blood chemistry including the cholesterol between the different housing systems (floor and cage) were not significant at $p<0.05$ or 0.01 . Contrary to this, Zita et al. [38] found that the blood cholesterol level was higher in birds raised in cages than on litter. However, the cholesterol, ALT, AST, and urea levels were significantly $(p<0.05$ or 0.01$)$ lower in rosemary and cinnamon groups than in the control group. The effect of interaction between dietary the interaction among EOs and housing systems was not significant $(p<0.05)$ on blood chemistry tests except for the blood phosphorus content, the highest levels were observed for birds fed diets enriched with cinnamon oil with a cage or floor system. Alagawany and Abd El-Hack [17] found that serum constituents were not significantly influenced by rosemary supplementation, except for urea and cholesterol. Moreover, Torki et al. [64] reported that birds given rosemary exhibited lower serum cholesterol and triglycerides concentration. The Ca and $\mathrm{P}$ were higher in rosemary and cinnamon groups than in the control group. 
Table 10. Blood chemistry of laying hens as affected by different housing systems, essential oils and their interaction during the experiment.

\begin{tabular}{|c|c|c|c|c|c|c|c|c|c|}
\hline \multicolumn{2}{|c|}{ Items } & $\begin{array}{l}\text { Cholesterol } \\
\text { (mg/dl) }\end{array}$ & $\begin{array}{l}\text { Protein } \\
\text { (g/dl) }\end{array}$ & $\begin{array}{l}\text { Calcium } \\
(\mathrm{m} \mathrm{mol} / \mathrm{L})\end{array}$ & $\begin{array}{l}\text { Phosphorus } \\
\text { (m mol/L) }\end{array}$ & $\begin{array}{l}\text { Urea (m } \\
\text { mol/L) }\end{array}$ & $\begin{array}{l}\text { Creatinine } \\
\text { (m mol/L) }\end{array}$ & $\begin{array}{c}\mathrm{ALT}^{1} \\
(\mathrm{U} / \mathrm{L})\end{array}$ & $\begin{array}{c}\mathrm{AST}^{2} \\
(\mathrm{U} / \mathrm{L})\end{array}$ \\
\hline \multicolumn{10}{|c|}{ Housing system } \\
\hline \multicolumn{2}{|l|}{ Cage } & 190.43 & 3.49 & 2.71 & 2.21 & 5.31 & 0.44 & 20.40 & 86.10 \\
\hline \multicolumn{2}{|l|}{ Floor } & 193.56 & 3.50 & 2.69 & 2.21 & 5.54 & 2.65 & 21.08 & 89.41 \\
\hline \multicolumn{10}{|c|}{ Essential oils (EOs) ${ }^{3}$} \\
\hline \multicolumn{2}{|c|}{0} & $206.50^{a}$ & 3.51 & $2.44^{\mathrm{c}}$ & $2.08^{c}$ & $5.75^{\mathrm{a}}$ & 0.51 & $22.62^{\mathrm{a}}$ & $99.37^{\mathrm{a}}$ \\
\hline \multicolumn{2}{|l|}{ Ros EO } & $187.30^{b}$ & 3.49 & $2.76^{\mathrm{b}}$ & $2.22^{b}$ & $5.35^{b}$ & 3.78 & $20.40^{b}$ & $83.70^{b}$ \\
\hline \multicolumn{2}{|c|}{ Cinn EO } & $182.20^{\mathrm{c}}$ & 3.48 & $2.89^{a}$ & $2.33^{\mathrm{a}}$ & $5.18^{b}$ & 0.35 & $19.20^{b}$ & $80.20^{c}$ \\
\hline \multicolumn{10}{|c|}{ Housing $\times$ EOs } \\
\hline \multirow{4}{*}{ Cage } & 0 & 204.50 & 3.54 & 2.43 & $2.09^{c}$ & 5.65 & 0.51 & 22.00 & 96.50 \\
\hline & Ros EO & 185.80 & 3.47 & 2.74 & $2.19^{b}$ & 5.18 & 0.44 & 20.40 & 81.40 \\
\hline & Cinn EO & 181.00 & 3.45 & 2.93 & $2.36^{\mathrm{a}}$ & 5.10 & 0.37 & 18.80 & 80.40 \\
\hline & 0 & 208.50 & 3.48 & 2.45 & $2.07^{c}$ & 5.85 & 0.50 & 23.25 & 102.25 \\
\hline \multirow{2}{*}{ Floor } & Ros EO & 188.80 & 3.51 & 2.77 & $2.26^{\mathrm{a}}$ & 5.52 & 7.12 & 20.40 & 86.00 \\
\hline & Cinn EO & 183.40 & 3.51 & 2.84 & $2.30^{\mathrm{a}}$ & 5.26 & 0.33 & 19.60 & 80.00 \\
\hline \multicolumn{2}{|l|}{ SEM $^{4}$} & 1.830 & 0.093 & 0.031 & 0.023 & 0.065 & 2.86 & 0.53 & 1.28 \\
\hline \multicolumn{10}{|c|}{ Probability } \\
\hline \multicolumn{2}{|c|}{ Housing system } & 0.057 & 0.883 & 0.636 & 0.797 & $<0.001$ & 0.373 & 0.145 & 0.006 \\
\hline \multicolumn{2}{|l|}{ EOs } & $<0.001$ & 0.966 & $<0.001$ & $<0.001$ & $<0.001$ & 0.427 & $<0.001$ & $<0.001$ \\
\hline \multicolumn{2}{|c|}{ Housing $\times$ EOs } & 0.919 & 0.797 & 0.144 & 0.026 & 0.372 & 0.429 & 0.533 & 0.067 \\
\hline
\end{tabular}

Means in the same column within each classification bearing different letters are significantly different $(p<0.05$ or 0.01). ${ }^{1}$ ALT: Alanine transferase. ${ }^{2}$ AST; Aspartate transferase. ${ }^{3}$ EOs: Essential oils, Ros EO: Rosemary essential oil, Cinn EO: Cinnamon essential oil. ${ }^{4}$ SEM: Standard error mean.

\section{Conclusions}

The supplementation of rosemary and cinnamon essential oils had great impacts on egg production and weight, some egg quality traits, feed intake and conversion, some haematological traits and blood chemistry, immunity, and antioxidant parameters. On the other hand, the different housing systems did not result in any positive or negative impact on these studied traits. However, the cage $\times$ cinnamon group was the highest in egg mass, and the lowest in FCR. Therefore, we have recommended the usage of rosemary or cinnamon essential oils at $300 \mathrm{mg} / \mathrm{kg}$ in layer's diet to improve its productive performance and egg production.

Author Contributions: Conceptualization, M.M.A.G. and M.F.E.; data curation, M.M.A.G., M.F.E., A.E.T., M.E.A.E.-H. and M.A.; formal analysis, A.E.T., M.E.A. and M.A.; funding acquisition, M.F.E., B.M.A. and M.M.E.; investigation, M.M.AG., M.F.E. and M.A.; methodology, M.M.A.G., M.F.E., A.E.T., M.E.A.E.-H., M.A., B.M.A. and M.M.E.; resources, M.M.A.G., A.E.T., M.E.A.E.-H. and B.M.A.; supervision, M.M.A.G., M.F.E. and M.A.; visualization, K.E.-S.; writing-original draft, B.M.A., M.M.E. and K.E.-S.; writing-review and editing, K.E.-S. and M.A. All authors have read and agreed to the published version of the manuscript.

Acknowledgments: Authors extend their appreciation to the Deanship of Scientific Research at King Saud University for funding this work through research group no. (RG-1439-81).

Conflicts of Interest: The authors declare no conflicts of interest.

\section{References}

1. El-Sabrout, K. Effect of rearing system and season on behaviour, productive performance and carcass quality of rabbit: A review. J. Anim. Behav. Biometeorol. 2018, 6, 102-108. [CrossRef]

2. Campbell, D.; de Haas, E.; Lee, C. A review of environmental enrichment for laying hens during rearing in relation to their behavioral and physiological development. Poult. Sci. 2019, 98, 9-28. [CrossRef] [PubMed] 
3. Wei, S.; Guo, Y.; Yan, P. Comparison of two housing systems on behaviour and performance of fattening pigs. J. Appl. Anim. Res. 2019, 47, 41-45. [CrossRef]

4. Englmaierová, M.; Tůmová, E.; Charvátová, V.; Skřivan, M. Effects of laying hens housing system on laying performance, egg quality characteristics, and egg microbial contamination. Czech J. Anim. Sci. 2014, 59, 345-352. [CrossRef]

5. El-Deek, A.; El-Sabrout, K. Behaviour and meat quality of chicken under different housing systems. World Poult. Sci. J. 2019, 75, 105-114. [CrossRef]

6. Rodić, V.; Perić, L.; Pavlovski, Z.; Milošević, N. Competitiveness of table eggs from noncage housing systems. Biotechnol. Anim. Husb. 2010, 26, 117-128. [CrossRef]

7. Nadia, R.L.; Hassan, R.A.; Qota, E.M.; Fayek, H.M. Effect of natural antioxidant on oxidative stability of eggs and productive and reproductive performance of laying hens. Int. J. Poult. Sci. 2008, 7, 134-150. [CrossRef]

8. Vinus, R.D.; Sheoran, N.; Maan, N.S.; Tewatia, B.S. Potential benefits of herbal supplements in poultry feed: A review. Pharma Innov. J. 2018, 7, 651-656.

9. Şimşek, U.; Çiftçi, M.; Özçelik, M.; Azman, M.; Tonbak, F.; Özhan, N. Effects of cinnamon and rosemary oils on egg production, egg quality, hatchability traits and blood serum mineral contents in laying quails (Coturnix coturnix Japonica). Ankara Üniv. Vet. Fak. Derg. 2015, 62, 229-236.

10. Dhama, K.; Karthik, K.; Khandia, R.; Munjal, A.; Tiwari, R.; Rana, R.; Khurana, S.K.; Ullah, S.; Khan, R.U.; Alagawany, M.; et al. Medicinal and therapeutic potential of herbs and plant metabolites/extracts countering viral pathogens-Current knowledge and future prospects. Curr. Drug Metab. 2018, 19, 236-263. [CrossRef]

11. Hayes, D.J.; Jensen, H.H. Lessons can be learned from Danish antibiotic ban. Feedstuffs 2003, 75, 17-18.

12. Zhai, H.; Liu, H.; Wang, S.; Wu, J.; Kluenter, A. Potential of essential oils for poultry and pigs. Anim. Nutr. 2018, 4, 179-186. [CrossRef] [PubMed]

13. Estevez, M.; Ramirez, R.; Ventanas, S.; Cava, R. Sage and rosemary essential oil versus BHT for the inhibition of lipid oxidative reactions in liver pate. LWT-Food Sci. Technol. 2007, 40, 58-65. [CrossRef]

14. Nakatani, N. Phenolic antioxidants from herbs and spices. BioFactors 2000, 13, 141-146. [CrossRef] [PubMed]

15. Alagawany, M.; Abd El-Hack, M.E.; Farag, M.R.; Gopi, M.; Karthik, K.; Malik, Y.S.; Dhama, K. Rosmarinic acid: Modes of action, medicinal values and health benefits. Anim. Health Res. Rev. 2017, 18, 167-176. [CrossRef]

16. Bölükbaşı, Ş.C.; Erhan, M.K.; Kaynar, Ö. The effect of feeding thyme, sage and rosemary oil on laying hen performance, cholesterol and some proteins ratio of egg yolk and Escherichia Coli count in feces. Arch. Geflügelk. 2008, 72, 231-237.

17. Alagawany, M.; Abd El-Hack, M.E. The effect of rosemary herb as a dietary supplement on performance, egg quality, serum biochemical parameters, and oxidative status in laying hens. J. Anim. Feed Sci. 2015, 24, 341-347. [CrossRef]

18. Arain, M.A.; Saeed, M.; Hassan, F.U.; Rashid, I.; Zohaib, R.; Bhutto, A.; Alagawany, M.; Shar, A.H. Phytochemistry and beneficial impacts of cinnamon (Cinnamomum Zeylanicum) as a dietary supplement in poultry diets. World. Poult. Sci. 2018, 74, 331-346.

19. NRC. Nutrition Requirements of Poultry, 9th ed.; National Academies Press: Washington, DC, USA, 1994.

20. Haugh, R.R. The Haugh unit for measuring egg quality. US Egg Poult. Mag. 1937, 43, 552-555.

21. Stoskopf, K.M. Clinical Pathology in: Fish Medicine, 1st ed.; W.B. Saunders Co.: Philadelphia, PA, USA, 1993; pp. 113-131.

22. Drabkin, D.L.; Austin, J.H. Spectrophotometric studies: Technique for the analysis undiluted blood and concentrated hemoglobin solutions. J. Biol. Chem. 1935, 112, 105-115.

23. Blaxhall, P.C.; Daisley, K.W. Routine haematological methods for use with fish blood. J. Fish Biol. 1973, 5 , 771-781. [CrossRef]

24. Lucky, Z. Methods for Diagnosis of Fish Diseases; Ameruno Publishing Co., PVT, Ltd.: New Delhi, IL, USA; Bombay, NY, USA, 1977.

25. Schalm, O.W.; Jain, N.C.; Carroll, E.J. Veterinary Haematology, 4th ed.; Lea, and Febiger: Philadephia, PA, USA, 1986.

26. Richmond, W. Preparation and properties of a cholesterol oxidase from Nocardia sp. and its application to the enzymatic assay of total cholesterol in serum. Clin. Chem. 1973, 19, 1350-1356. [CrossRef]

27. Allain, C.C.; Poon, L.S.; Chan, C.S. Enzymatic determination of total cholesterol in serum. Clin. Chem. 1974, 20, 470. [CrossRef] 
28. Gornall, A.G.; Bardawell, C.J.; David, M.M. Determination of serum proteins by means of the biuret reaction. J. Biol. Chem. 1949, 177, 751-766.

29. Reitman, S.; Frankel, S. A colorimetric method for the determination of serum glutamic oxalacetic and glutamic pyruvic transaminases. Am. J. Clin. Pathol. 1957, 28, 56-63. [CrossRef]

30. Bartels, H.; Bohmer, M.; Heierli, C. Serum creatinine determination without protein precipitation. Clinica. Chemica. Acta. 1972, 37, 193-197. [CrossRef]

31. Fawcett, J.K.; Scott, J.E. A rapid and precise method for the determination of Urea. J. Clin. Pathol. 1960, 13, 156-159. [CrossRef]

32. Jo, C.; Ahn, D.U. Fluorometric analysis of 2-thiobarbituric acid reactive substances in turkey. Poult. Sci. 1998, 77, 475-480. [CrossRef]

33. Paglia, D.E.; Valentine, W.N. Studies on the quantitative and qualitative characterization of erythrocyte glutathione peroxidase. J. Lab. Clin. Med. 1967, 70, 158-169.

34. Martin, J.P., Jr.; Dailey, M.; Sugarman, E. Negative and positive assays of superoxide dismutase based on haematoxylin auto-oxidation. Arch. Biochem. Biophys. 1987, 255, 329-336. [CrossRef]

35. Stott, G.H.; Fellah, A. Colostral immunoglobulin absorption linearly related to concentration for calves. J. Dairy Sci. 1983, 66, 1319-1328. [CrossRef]

36. Kawahara, E.; Ueda, T.; Nomura, S. In vitro phagocytic activity of white spotted shark cells after injection with Aeromonas salmonicida extra cellular products. Gyobyo. Kenkyu. Jpn. 1991, 26, 213-214. [CrossRef]

37. SAS Institute. SAS/STAT ${ }^{\circledR}$ Guide for Personal Computers, Version 9.1 ed.; SAS Institute, Inc.: Cary, NC, USA, 2002.

38. Zita, L.; Jeníková, M.; Härtlová, H. Effect of housing system on egg quality and the concentration of cholesterol in egg yolk and blood of hens of native resources of the Czech Republic and Slovakia. J. Appl. Poult. Res. 2018, 27, 380-388. [CrossRef]

39. Ding, X.; Yu, Y.; Su, Z.; Zhang, K. Effects of essential oils on performance, egg quality, nutrient digestibility and yolk fatty acid profile in laying hens. Anim. Nutr. 2017, 3, 127-131. [CrossRef]

40. Cufadar, Y. Effects of dietary different levels of rosemary essential oil on performance and eggshell quality parameters in laying hens. Selcuk. J. Agric. Food Sci. 2018, 32, 454-457. [CrossRef]

41. Zhang, Y.; Gong, J.; Yu, H.; Guo, Q.; Defelice, C.; Hernandez, M.; Yin, Y.; Wang, Q. Alginate-whey protein dry powder optimized for target delivery of essential oils to the intestine of chickens. Poult. Sci. 2014, 93, 2514-2525. [CrossRef]

42. Hippenstiel, F.; Abdel-Wareth, A.; Kehraus, S.; Südekum, K. Effects of selected herbs and essential oils, and their active components on feed intake and performance of broilers-a review. Arch. Geflügelk. 2011, 75, 226-234.

43. Bozkurt, M.; Aysul, N.; Küçükyilmaz, K.; Aypak, S.; Ege, G.; Çatli, A.; Akşit, H.; Çöven, F.; Seyrek, K.; Çınar, M. Efficacy of in-feed preparations of an anticoccidial, multienzyme, prebiotic, probiotic, and herbal essential oil mixture in healthy and Eimeria spp.-infected broilers. Poult. Sci. 2014, 93, 389-399. [CrossRef]

44. Bento, M.; Ouwehand, A.; Tiihonen, K.; Lahtinen, S.; Nurminen, P.; Saarinen, M.; Schulze, H.; Mygind, T.; Fischer, J. Essential oils and their use in animal feeds for monogastric animals-Effects on feed quality, gut microbiota, growth performance and food safety: A review. Vet. Med. 2013, 58, 449-458. [CrossRef]

45. Kurekci, C.; Al Jassim, R.; Hassan, E.; Bishop-Hurley, S.L.; Padmanabha, J.; McSweeney, C.S. Effects of feeding plant-derived agents on the colonization of Campylobacter jejuni in broiler chickens. Poult. Sci. 2014, 93, 1-10. [CrossRef]

46. O'Bryan, C.A.; Pendleton, S.J.; Crandall, P.G.; Ricke, S.C. Potential of plant essential oils and their components in animal agriculture-in vitro studies on antibacterial mode of action. Front. Vet. Sci. 2015, 2, 1-8. [CrossRef] [PubMed]

47. Jamroz, D.; Wertelecki, T.; Houszka, M.; Kamel, C. Influence of diet type on the inclusion of plant origin active substances on morphological and histochemical characteristics of the stomach and jejunum walls in chicken. J. Anim. Physiol. Anim. Nutr. 2006, 90, 255-268. [CrossRef] [PubMed]

48. Jang, I.; Ko, Y.; Kang, S.; Lee, C. Effect of a commercial essential oil on growth performance, digestive enzyme activity and intestinal microflora population in broiler chickens. Anim. Feed. Sci. Technol. 2007, 134, 304-315. [CrossRef]

49. Yang, X.; Xin, H.; Yang, C.; Yang, X. Impact of essential oils and organic acids on the growth performance, digestive functions and immunity of broiler chickens. Anim. Nutri. 2018, 4, 388-393. [CrossRef] [PubMed] 
50. Mathlouthi, N.; Bouzaienne, T.; Oueslati, I.; Recoquillay, F.; Hamdi, M.; Urdaci, M.; Bergaoui, R. Use of rosemary, oregano, and a commercial blend of essential oils in broiler chickens: In vitro antimicrobial activities and effects on growth performance. J. Anim. Sci. 2012, 90, 813-823. [CrossRef]

51. Zeng, Z.; Zhang, S.; Wang, H.; Piao, X. Essential oil and aromatic plants as feed additives in non-ruminant nutrition: A review. J. Anim. Sci. Biotechnol. 2015, 6, 1-10. [CrossRef]

52. Garcia, V.; Catala-Gregori, P.; Hernandez, F.; Megias, M.; Madrid, J. Effect of formic acid and plant extracts on growth, nutrient digestibility, intestine mucosa morphology, and meat yield of broilers. J. Appl. Poult. Res. 2007, 16, 555-562. [CrossRef]

53. Amad, A.; Manner, K.; Wendler, K.; Neumann, K.; Zentek, J. Effects of a phytogenic feed additive on growth performance and ideal nutrient digestibility in broiler chickens. Poult. Sci. 2011, 90, 2811-2816. [CrossRef]

54. Tumova, E.; Ebeid, T. Effect of housing system on performance and egg quality characteristics in laying hens. Sci. Agric. Bohem. 2003, 34, 73-80.

55. Botsoglou, N.; Florou-Paneri, P.; Botsoglou, E.; Dotas, V.; Giannenas, I.; Koidis, A.; Mitrakos, P. The effect of feeding rosemary, oregano, saffron and $\alpha$-tocopheryl acetate on hen performance and oxidative stability of eggs. S. Afr. J. Anim. Sci. 2005, 35, 143-151. [CrossRef]

56. Hoerr, F.J. Clinical aspects of immunosuppression in poultry. Avian Dis. 2010, 54, 2-15. [CrossRef]

57. Shini, S.; Huff, G.R.; Shini, A.; Kaiser, P. Understanding stress-induced immuno-suppression: Exploration of cytokine and chemokine gene profiles in chicken peripheral leukocytes. Poult. Sci. 2010, 89, 841-851. [CrossRef]

58. Miguel, M. Antioxidant activity of medicinal and aromatic plants. A review. Flavour. Fragr. J. 2010, 25, 291-312. [CrossRef]

59. Placha, I.; Takacova, J.; Ryzner, M.; Cobanova, K.; Laukova, A.; Strompfova, V.; Venglovska, K.; Faix, S. Effect of thyme essential oil and selenium on intestine integrity and antioxidant status of broilers. Br. Poult. Sci. 2014, 55, 105-114. [CrossRef]

60. Lee, K.W.; Everts, H.; Kappert, H.; Frehner, M.; Losa, R.; Beynen, A. Effects of dietary essential oil components on growth performance, digestive enzymes and lipid metabolism in female broiler chickens. Br. Poult. Sci. 2003, 44, 450-457. [CrossRef]

61. Khan, R.; Naz, S.; Nikousefat, Z.; Tufarelli, V.; Laudadio, V. Thymus vulgaris: Alternative to antibiotics in poultry feed. World Poult. Sci. J. 2012, 68, 401-408. [CrossRef]

62. Brenes, A.; Roura, E. Essential oils in poultry nutrition: Main effects and modes of action. Anim. Feed Sci. Technol. 2010, 158, 1-14. [CrossRef]

63. Franz, C.; Baser, K.; Windisch, W. Essential oils and aromatic plants in animal feeding-a European perspective. A review. Flavour Fragr. J. 2010, 25, 327-340. [CrossRef]

64. Torki, M.; Sedgh-Gooya, S.; Mohammadi, H. Effects of adding essential oils of rosemary, dill and chicory extract to diets on performance, egg quality and some blood parameters of laying hens subjected to heat stress. J. Appl. Anim. Res. 2018, 46, 1118-1126. [CrossRef]

(C) 2020 by the authors. Licensee MDPI, Basel, Switzerland. This article is an open access article distributed under the terms and conditions of the Creative Commons Attribution (CC BY) license (http://creativecommons.org/licenses/by/4.0/). 